\title{
FOLYÓN TÖRTÉNŐ OLAJSZENNYEZÉSEK ÉS AKTUÁLIS MEGOLDÁSI MÓDSZER VIZSGÁLATA
}

\section{ANALYSES OF RIVER OIL-SPILLS AND ACTUAL SOLVING METHODS}

\author{
Kisfaludi-Bak Zsombor ${ }^{1,2}$ \\ ${ }^{1}$ Erdélyi Múzeum-Egyesület, Müszaki Tudományok Szakosztálya, Kolozsvár, Románia, kisfaludi.zsombor@eme.ro \\ ${ }^{2}$ Kolozsvári Müszaki Egyetem, Építőmérnöki Kar, Tartószerkezet-mechanikai Tanszék, Kolozsvár, Románia, \\ zsombor.kisfaludi@mecon.utcluj.ro
}

\begin{abstract}
Nowadays, there is an increasing emphasis on the problem of water quality. Of the many polluting effects, oil pollution is perhaps the most harmful, but its effects are being studied mostly on large seas and oceans worldwide. In the case of Transylvania and probably the entire country, pollution of rivers by oil - based on yearly occurrence - has a larger effect than that of sea pollution. Every year we observe 40-55 such water pollution events, therefore, analysis and investigation of solution methods is of great importance. This paper attempts to shed light on this issue, presenting also the method currently used by the Romanian Water Authority.
\end{abstract}

Keywords: water pollution, oil, spill-sorb, wave propagation.

\section{Összefoglalás}

Napjainkban egyre nagyobb hangsúly helyeződik a vízminőség problémájára. Számos szennyező hatás közül talán a legkárosabbak az olajszennyeződések, melyek hatását világviszonylatban is főleg tengereken, óceánokon vizsgálják. Erdély tekintetében mindenképpen, de talán egész Románia tekintetében is nagyobb hatással bírnak a folyóvízi olajszennyeződések. Évente 40-55 ilyen vízszennyezést figyelhetünk meg, így elemzésük, megoldási módszereik vizsgálata nagy jelentőséggel bír. Erre próbál rávilágítani ezen dolgozat, mely kitér a Román Vízügyi Hatóság által alkalmazott módszerre is.

Kulcsszavak: vízszennyezés, olaj, spill-sorb, terjedési hullám.

\section{Bevezetés}

Az olajszennyeződések gyakorisága egyenesen arányosan nőtt az olajkitermelés térnyerése nyomán. Legtöbb ilyen jellegű vízszennyezés az óceánokon történik az olajkutak közelében. Az óceánokon, nyílt vizeken történő olajszennyeződések terjedési sebessége a szélsebesség függvényében változik, a felületi sebesség átlagosan a szélsebesség 1,3-1,4 \%-át teszi ki. [1]

A folyóvizeken történő olajszennyeződések terjedési sebességének vizsgálatához szükségszerű a folyószakasz hozamainak, keresztmetszetének ismerete, így továbbiakban egy tanulmányeset kapcsán vizsgáljuk az említett terjedési sebességet.

\section{Szennyezett szakasz vizsgálata}

Vízszennyezési vészhelyzetek esetén egyik legfontosabb adatnak számít a szennyezett folyó vízfelszínén mért sebesség. Jelen elemzés tárgya a Kis-Szamos folyó (II.1.31) Kolozsvár utáni szakasza, vagyis a Nádas folyó torkolata utáni szakasz. A hozamok számításba vett értéke a sokéves átlaghozam, mely az 1. táblázatban van feltüntetve (összehasonlításként megjelenik a Kis-Szamos legnagyobb mellékfolyójának - Nádasnak - sokéves hozama is).

Fontos megjegyezni, hogy a vízfelszíni sebességek mértékére nagy hatással van a hozamváltozás. Ezen értékváltozások amplitúdójának érzé- 
kelése céljából érdemes megfigyelni a többéves átlaghozam és a folyó maximális hozamai (2. táblázat) közötti különbségeket.

A vizsgált szakasz két keresztmetszetén hidraulikai modellezések lettek végezve a sokéves hozamok és a 0,2\%-os maximumhozamok esetén is (a 0,2\%-os hozam előfordulási periódusa 500 év). A meder rugalmassági állandója a számításokban 0,040. A végzett modellezések (1. ábra) az Amerikai Katonai Mérnökség HEC-Ras-programja segítségével valósultak meg, mely ChézyManning-hidraulikai modellt alkalmaz.

1. táblázat. Sokéves átlaghozamok a vizsgált területen [2]

\begin{tabular}{|l|c|c|}
\hline \multicolumn{1}{|c|}{ Folyó } & Kataszteri szám & $\begin{array}{c}\text { Sokéves átlag- } \\
\text { hozam }\end{array}$ \\
\hline Kis-Szamos & II.1.31 & $21,2 \mathrm{~m}^{3} / \mathrm{s}$ \\
\hline Nádas & II.1.31.14 & $1,3 \mathrm{~m}^{3} / \mathrm{s}$ \\
\hline
\end{tabular}

3. táblázat. Sokéves átlaghozammal számolt vízfelszíni sebességek

\begin{tabular}{|l|c|c|}
\hline \multicolumn{1}{|c|}{} & $\mathbf{1}$ & $\mathbf{2}$ \\
\hline Hozam & $21,2 \mathrm{~m}^{3} / \mathrm{s}$ & $21,2 \mathrm{~m}^{3} / \mathrm{s}$ \\
\hline Felületi szélesség & $21,22 \mathrm{~m}$ & $22,62 \mathrm{~m}$ \\
\hline Metszet-minimumpont & $323,04 \mathrm{~m}$ & $322,50 \mathrm{~m}$ \\
\hline Számolt vízszint & $323,67 \mathrm{~m}$ & $323,11 \mathrm{~m}$ \\
\hline Aktív kereszt-metszet & $9,85 \mathrm{~m}^{2}$ & $10,05 \mathrm{~m}^{2}$ \\
\hline Felületi sebesség & $2,15 \mathrm{~m} / \mathrm{s}$ & $2,11 \mathrm{~m} / \mathrm{s}$ \\
\hline
\end{tabular}

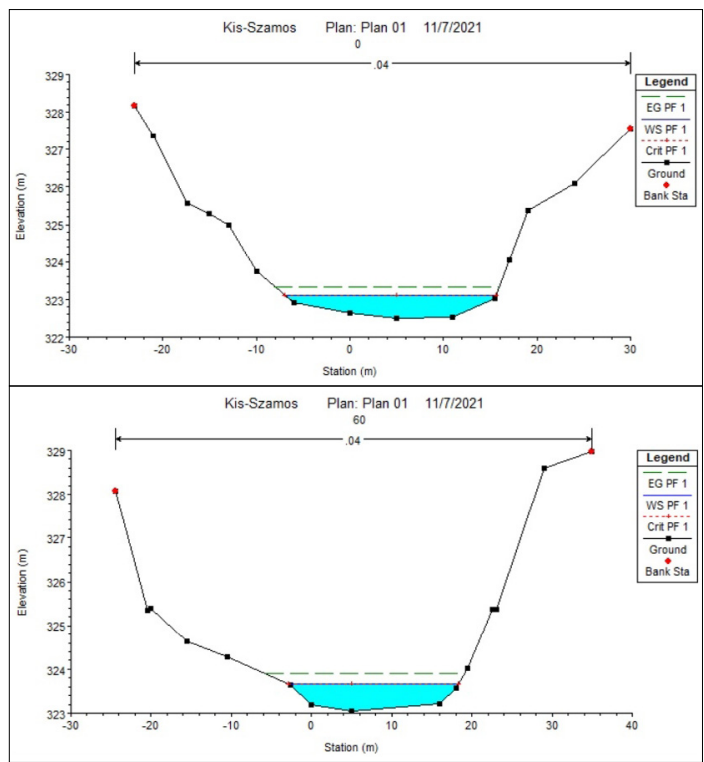

1. ábra. Sokéves hozammal számolt vízszint két keresztmetszeten
A sokéves hozammal elért eredmények a 3. táblázatban tekinthetők meg. A két keresztmetszeten elvégzett sokéves átlaghozammal modellezett Kis-Szamos folyásának felületi sebességei 2,11$2,15 \mathrm{~m} / \mathrm{s}$ között változtak.

Külön modellezés tárgya volt az 500 évente elöforduló hozam (0,2\%-os maximális hozam) hidrodinamikai elemzése (2. ábra).

A 0,2\%-os maximumhozammal elért eredmények a 4. táblázatban tekinthetők meg. A két keresztmetszeten elvégzett 0,2\%-os maximumhozammal modellezett Kis-Szamos folyásának felületi sebességei 5,22-5,29 m/s között változtak.

2. táblázat. A Kis-Szamos maximális hozamai a Nádas torkolata utáni pontban

\begin{tabular}{|c|c|c|}
\hline $\begin{array}{c}\text { Sztereó 70 } \\
\text { Koordináták }\end{array}$ & \multicolumn{2}{|c|}{$\begin{array}{c}\mathbf{Q}_{\max } \mathbf{p} \% \\
\left(\mathbf{m}^{3} / \mathbf{s}\right)\end{array}$} \\
\hline $\mathrm{X}=393652.14$ & $1 \%$ & $515 \mathrm{~m}^{3} / \mathrm{s}$ \\
\cline { 2 - 3 } $\mathrm{Y}=588821.53$ & $0,2 \%$ & $694 \mathrm{~m}^{3} / \mathrm{s}$ \\
\hline
\end{tabular}

4. táblázat. 0,2\%-os maximumhozammal számolt vízfelszíni sebességek

\begin{tabular}{|l|c|c|}
\hline & \multicolumn{1}{|c|}{} & $\mathbf{2}$ \\
\hline Hozam & $694 \mathrm{~m}^{3} / \mathrm{s}$ & $694 \mathrm{~m}^{3} / \mathrm{s}$ \\
\hline Felületi szélesség & $48,38 \mathrm{~m}$ & $46,38 \mathrm{~m}$ \\
\hline Metszet-minimumpont & $323,04 \mathrm{~m}$ & $322,50 \mathrm{~m}$ \\
\hline Számolt vízszint & $326,82 \mathrm{~m}$ & $326,74 \mathrm{~m}$ \\
\hline Aktív kereszt-metszet & $133,08 \mathrm{~m}^{2}$ & $131,13 \mathrm{~m}^{2}$ \\
\hline Felületi sebesség & $5,22 \mathrm{~m} / \mathrm{s}$ & $5,29 \mathrm{~m} / \mathrm{s}$ \\
\hline
\end{tabular}

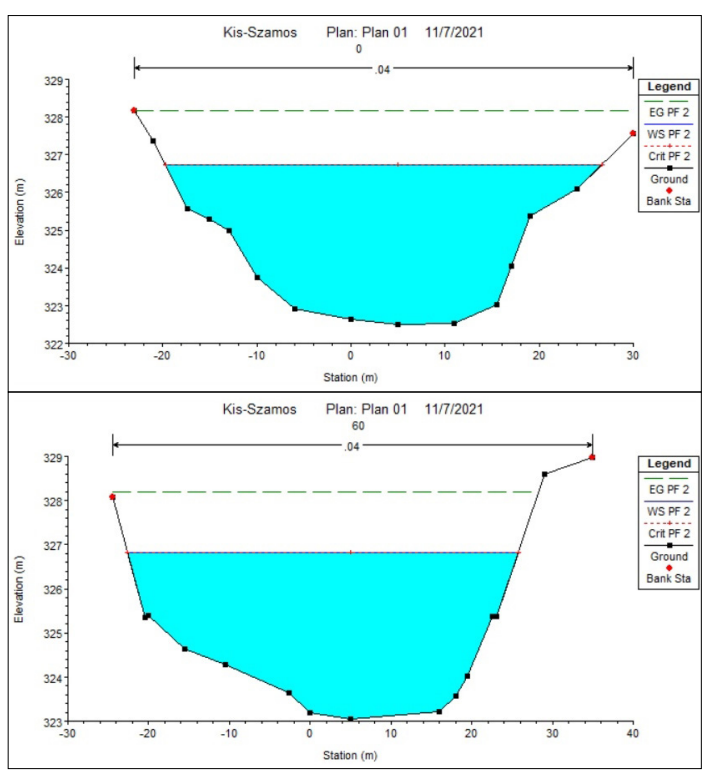

2. ábra. 0,2\%-os maximális hozammal számolt vízszint a két keresztmetszeten 


\section{Bevetésnél használt „spill-sorb” anyag}

A Román Vízügyi Hatóság jóvoltából lehetőségem volt tesztelni a bevetéseknél használt abszorpciós anyagot, melyet az Eco Tech Service Kft. gyárt. Egy korábban publikált dolgozatban bemutatásra kerültek az eredmények, alábbiakban képes formában (3. ábra) figyelhető meg a speciális anyag hatása. [3]

A gyártó által kiadott műszaki leírás alapján a speciális anyag lekötési kapacitása - általános szennyeződés esetén - saját súlyának 8-12-szerese. [4]

Mivel a feltüntetett szennyeződéseknél az olajszennyeződés a legagresszívebbnek számít, így 8-szoros saját súly lekötéssel számolunk.

\section{Terjedési folyamat, megoldás}

Az olajréteg terjedési sebessége nagymértékben függ az olajréteg vastagságától. A 2013-as, Kis-Szamoson történt olajszennyezés esetén az olajréteg vastagsága $1 \mathrm{~mm}$ alatti volt, amint a 4 . ábrán is megfigyelhető a réteg áttetszőségén.

Hasonló vékony olajréteg esetén a terjedési sebesség egyenlőnek tekinthető a víz felszínén mért sebességgel. Ezen adatokkal számolva sokéves átlaghozam esetén egy kolozsvári szennyeződés 9 óra és 32 perc alatt ér el a Kis-Szamos torkolatáig. 0,2\%-os maximális hozam esetén ugyanezen táv 3 óra 48 perc alatt lesz megtéve.

\section{Következtetések és további tervek}

Következésképpen egy 2013-as esethez hasonló, a Kis-Szamos kolozsvári szakaszán történő olajszennyezés kezelésére a katonaság, katasztrófavédelem egységeinek átlagosan 9 óra 32 perce, maximális hozamok esetén csupán 3 óra 48 perce van kezelni a szennyezést a folyó torkolata előtt.

A jelenleg használt abszorpciós anyagból az $1 \mathrm{~m}$ vastag rétegű olajszennyeződésre 106-112 g elhintése szükséges négyzetméterenként, ami ilyen vékony rétegek esetén nehézséget jelenthet. Pozitívum, hogy a bevetett abszorpciós anyag 72 órán keresztül képes a vízfelszínen maradni [4].

További tervekhez tartozik egy bővebb parametrikus vizsgálat, mely során előkészíthető egy bevetést segítő módszer. Aktuálisan hasonló esetekben a szennyeződés felszíni felfogásához munkagépek által függesztett farönköket használnak, ugyancsak további terv a nagyvárosok utáni szakaszokon speciális úszógátak tervezése/vizsgálata.
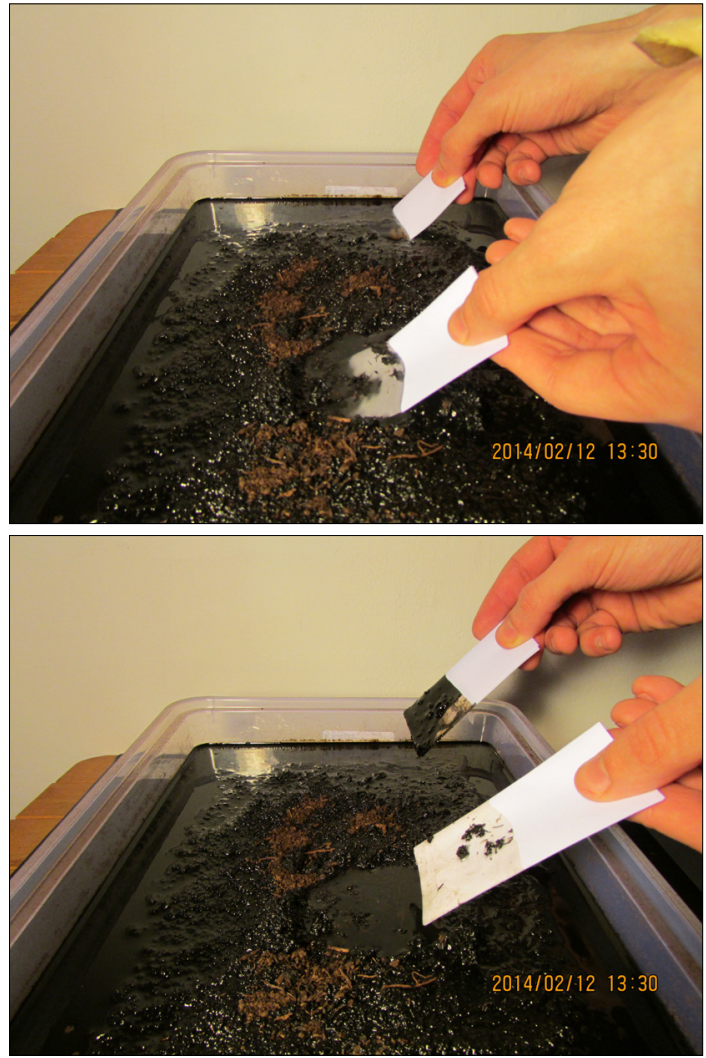

3. ábra. Abszorpciós „spill-sorb” anyag tesztelése (az olajfelületre szórt anyag kivágása után nem marad szennyeződés) [3]

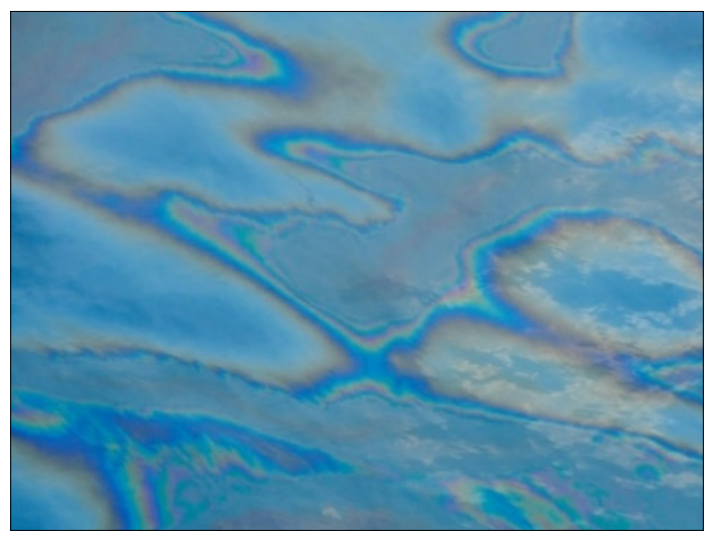

4. ábra. Vízfelszín a 2013-as kis-szamosi olajszennyeződést követően (vékony olajréteg) [5]

\section{Köszönetnyilvánítás}

Köszönet illeti az Erdélyi-Múzeum Egyesület Müszaki Tudományok Szakosztályát a jelen publikáció megjelenésében nyújtott támogatásáért. 


\section{Szakirodalmi hivatkozások}

[1] Buranapratheprat A., Tangjaitrong S.: Hydrodynamic Model for Oil Spill Trajectory Prediction. The Second OMISAR Workshop on Ocean Models, session 6 on Ocean Transport Models and Marine Ecosystem Models, 2000. https://doi.org/10.1.1.551.1752

[2] Atlasul cadastrului apelor din România. Partea 1 - Date morfo-hidrografice asupre rețelei hidrografice de suprafață. Ministerul Mediului, București, 1992.
[3] Kisfaludi-Bak Zs.: Vízszennyezési vészhelyzetek kezelése, megoldási módszerei. In: Fiatal Műszakiak Tudományos Ülésszaka XIX., Kolozsvár, Románia, XIX. 2014. 237-241.

https://doi.org/10.36243/fmtu-2014.052

[4] Eco Tech Service Kft.: Müszaki leírás „Spill-Sorb”, 5-6.

[5] Poluare cu ulei pe Someșul Mic (Olajszennyezés a Kis-Szamoson) - Monitorul CJ. 2013.

http://www.monitorulcj.ro/actualitate/26973-poluare-cu-petrol-pe-raul-somesul-mic (letöltve: 2021. július 16.) 